\title{
Determining Jurisdiction in Cyberspace: The "Zippo" Test or the "Effects" Test?
}

\author{
Julia Alpert Gladstone \\ Bryant College, Smithfield, Rhode Island, USA
}

\author{
jgladsto@bryant.edu
}

\begin{abstract}
Engaging in online activity is m longer a novel experience yet, there are many unresolved issues remaining in determining jurisdictionover the person which is a fundamental legal threshold in order to pursue one's legal rights. Two principal models for testing jurisdiction have moved to the forefront. One is the "Zippo test," after the case in which it was first articulated which bases jurisdiction over a nonresident website on the degree of interactivity between the website and the forum. This test has been found by cyberlawyers, scholars and many courts to be inexact and therefore not particularly helpful. Consequently, the "effects" test has evolved which focuses on the effects intentionally caused within the forum by a defendant's online conduct outside the forum. After summarizing the background and evolution of both the Zippo and effects tests, this article demonstrates that the courts are not embracing the effects test as a panacea to the dilemma of determining jurisdiction, but rather a combination of both the Zippo and the effects test is being employed. Oftentimes a court will begin its case analysis of with the Zippo test but completes the jurisdictional determination using the effects test. It is therefore advisable for attorneys advocating jurisdiction to use both tests, since the effects test may work where the slidingscale of Zippo might not.
\end{abstract}

Keywords: cyberspace, jurisdiction, sovereignty, intent, interactivity, due process, international, comity

\section{Introduction}

Engaging in online activity is no longer a novel or unique experience; it is quite ordinary, in fact, in 605.60 million people were reported to have been online globally in 2002 (NUA Internet Surveys, 2002) and it is anticipated that $\$ 4.5$ billion will be spent during the Christmas season online in Europe alone, (Jupiter Research, 2002). There are many unresolved issues remaining in determining jurisdiction in cyberspace over the person which is a fundamental legal threshold in order to pursue one's legal rights both in the real world and cyberspace. This electronic environment that mirrors the physical world in many ways challenges the traditional methods for finding presence to assert jurisdiction. Questions of jurisdiction in cyberspace are essentially practical. First, does a person who posts information on the World Wide Web have to comply with the laws of every state or nation from which the website can be accessed? Second, do the courts of every state or nation from which information on the Web can be accessed have personal jurisdiction over the creator

Material published as part of these proceedings, either on-line or in print, is copyrighted by Informing Science. Permission to make digital or paper copy of part or all of these works for personal or classroom use is granted without fee provided that the copies are not made or distributed for profit or commercial advantage AND that copies 1) bear this notice in full and 2) give the full citation on the first page. It is permissible to abstract these works so long as credit is given. To copy in all other cases or to republish or to post on a server or to redistribute to lists requires specific permission from the publisher at Publisher@InformingScience.org of the information and the operator of the site?

Sorting out the answers to these two basic questions has generated numerous court decisions and commentary over the past several years. There have been diverse attempts to develop uniform principles of jurisdictio $n$ in cyberspace namely the American Bar Association's Jurisdiction in Cyberspace Project 2000 and the Hague Convention on 


\section{Determining Jurisdiction In Cyberspace}

Jurisdiction and Recognition and Enforcement of Foreign Judgements in Civil and Commercial Matters but worldwide consensus on rules to apply to determine jurisd ic tion remains elusive. Two principal models for testing jurisdiction have moved to the forefront. One is the "Zippo test," after the case in which it was first articulated Zippo Mfg. Co. v. Zippo Dot Com, Inc., 952 F. Supp. 1119 (W.D. Pa. 1996) The Zippo test bases jurisdiction over a non-resident website on the degree of interactivity between the website and the forum. Since mere accessibility of a non-resident's website from the forum is the least interactive, under Zippo a passive website is insufficient to establish specific jurisdiction. In addition to Zippo, courts have been analyzing Internet jurisdiction issues under the so-called "effects" test which is derived from the pre Internet case of Calder v Jones, 465 U.S. 783 (1984). This test does not focus on the degree of interactivity between forum resident and non-forum defendant, but rather on the effects intentionally caused within the forum by a defendant's online conduct outside the forum.

There is a general consensus among cyberlawyers and scholars (Geist) that the effects test marks the wave of the future in cyberspace jurisdiction issues, because it can produce "greater certainty" of outcome in jurisdictional matters. While the effects test clearly supplies a useful frame of reference whenever personal jurisdiction is an issue, the Zippo test is still often used to define jurisdiction; through midJune 2002, 164 decisions of federal and state courts involving Internet jurisdiction had cited Zippo, with 46 of these occurring since the start of 2001.

After summarizing the background and evolution of both the Zippo and effects tests, this article seeks to demonstrate that the courts are not embracing the effects test as a panacea to the dilemma of determining jurisdiction, but rather a combination of both the Zippo and the effects test is being employed. The effects test will likely have a growing role in e-commerce disputes, but experience so far suggests that:1)it tends to be more applicable to certain kinds of non-commercial disputes than to others,2) it can pose problems of subjectivity comparable to those that have arisen in the Zippo test, and 3) in certain kinds of e-commerce disputes, particularly where the defendant operates an online business engaged in transactions in the forum, the Zippo approach may be more applicable than the effects test. Oftentimes a court will begin its case analysis with the Zippo test but complete the jurisdictional determination using the effects test.

\section{Basic Jurisdiction Principles}

\section{Jurisdiction in International Law}

International law limits a country's authority to exercise jurisdiction in cases that involve interests or activities of non-residents. First, there must exist "jurisdiction to prescribe." If jurisdiction to prescribe exists, "jurisdiction to adjudicate" and, "jurisdiction to enforce" will be examined. The foregoing three types of jurisdiction are often interdependent and based on similar considerations.

"Jurisdiction to prescribe" means that the substantive laws of the forum country are applicable to the particular persons and circumstances. When a country has jurisdiction to prescribe, it can appropriately apply its legal norms to conduct. Simply stated, a country has jurisdiction to prescribe law with respect to: (1) conduct that, wholly or in substantial part, takes place within its territory; (2) the status of persons, or interests in things, present within its territory; (3) conduct outside its territory that has or is intended to have substantial effect within its territory; (4) the activities, interests, status, or relations of its nationals outside as well as within its territory; and (5) certain conduct outside its territory by persons who are not its nationals that is directed against the security of the country or against a limited class of other national interests. "Jurisdiction to adjudicate" means that the tribunals of a given country may resolve a dispute in respect to a person or thing where the country has jurisdiction to prescribe the law that is sought to be enforced. The exercise of jurisdiction by a country is subject also to the requirement of reasonability. States exercise jurisdiction to adjudicate on the basis of various links, including the defen- 
dant's presence, conduct, or, in some cases, ownership of property within the country, conduct outside the state having a "substantial, direct and foreseeable effect" within the country or the defendant's nationality, domicile, or residence in the country. Exercise of judicial jurisdiction on the basis of such links is on the whole accepted as "reasonable"; reliance on other bases, such as the nationality of the plaintiff or the presence of property unrelated to the claim, is generally considered "exorbitant."

A country may employ judicial or non judicial measures to induce or compel compliance or punish noncompliance with its laws or regulations, provided it has "jurisdiction to prescribe." Thus, a country may not exercise authority to enforce law that it had no jurisdiction to prescribe. A country may employ enforcement measures against a person located outside its territory if (a) the person is given mtice of the claims or charges against him that is reasonable in the circumstances; (b) the person is given an opportunity to be heard, ordinarily in advance of enforcement; and (c) where enforcement is through the courts, if the country has jurisdiction to adjudicate.

Cutting across the foregoing international law criteria is a general requirement of reaso nableness. Thus, even when one of the foregoing bases of jurisdiction is present, a country may not exercise jurisdiction to prescribe law with respect to a person or activity having connection with another country if the exe $r$ cise of jurisdiction is unreasonable. The net effect of the reasonableness standard is to require more close contact between a foreign defendant and the forum country than is required under constitutional due process.

\section{Personal Jurisdiction in the United States}

In the U.S., states exercise jurisdiction over non-residents under their respective long-arm statutes, the exercise of which must meet constitutional due process. In brief, to exercise personal jurisdiction over a defendant, a U.S. court must undertake a two-step inquiry. First, the court must apply the rele vant state long-arm statute to see if it permits the exercise of personal jurisdiction. Next, the court must apply the precepts of the Due Process Clause of the U.S. Constitution.

Personal jurisdiction under the Due Process Clause depends upon "the relationship among the defendant, the forum, and the litigation," Shaffer v Heitner, 433 U.S. 186 (1977). Physical presence within the forum is not required to establish personal jurisdiction over a no nresident defendant, Burger King Corp $v$ Rudzewicz, 471 U.S. 462 1985). Instead, the plaintiff must show that the defendant has purposefully directed its activities toward the residents of the forum state, or otherwise "purposefully availed itself of the privilege of conducting activities within the forum State, thus invoking the benefits and protections of its laws," Hanson v Denckla 357 U.S. 235 (1985).

Where a plaintiff's claim is related to or arises out of the defendant's contacts with the forum, the court is said to exercise "specific jurisdiction." In order for specific jurisdiction to be properly exercised under the Due Process Clause, the plaintiff must satisfy a two-part test. First, the plaintiff must show that the defendant has constitutionally sufficient "minimum contacts" with the forum. For "minimum contacts" to be satisfied, the plaintiff's cause of action must arise out of or result from the out-of-state defendant's contacts with the forum or the defendant must have purposely directed its activities relating to the plaintiff's cause of action toward the forum or otherwise availed itself of the privilege of conducting activities in the forum. Second, for jurisdiction to be exercised the court must determine, in its discretion, that to do so would comport with "traditional notions of fair play and substantial justice," International Shoe Co. v. Washington, 326 U.S. 310 (1945).

\section{Jurisdiction in the European Union}

Fundamentals of jurisdiction within European countries are based on statute or regulation, instead of constitutional due process applied in case law, as in the U.S. Nonetheess, the results under both sys- 
tems have a good deal in common. The Brussels Convention is the controlling document for jurisdictional issues within the European Union ("E.U."). Convention on Jurisdiction and the Enforcement of Judgments in Civil and Commercial Matters (Sep. 30, 1968), 1998 OFFICIAL J. C027, 0001-0027 ["Brussels Convention"]. It sets forth the following basic rules. First, a person who is domiciled in an E.U. member country may be sued in that country. Second, in contract matters, a person may be sued in the place of performance of the obligation in question. Third, a person may be sued in tort matters in the place where the event causing harm occurred. Fourth, a consumer may be sued only in the consumer's country of domicile, while a cons umer may elect to bring an action in either his domicile or in the other party's domicile, so long as the consumer was subject to a specific solicitation or advertising in the consumer's domicile. Finally, in entering into contracts not involving a consume $r$, the parties can agree on a forum for disputes.

Since jurisdiction in European countries is not limited by constitutional due process as it is in the U.S., the Brussels Convention does not require "minimum contacts" between the forum and the defendant. The Convention permits assertion of jurisdiction over a defendant if conduct wholly outside the forum resulted in a tort injury to the plaintiff within the forum. In certain instances, at least, E.U. members construe their jurisdiction to extend to conduct on the Internet that offends policies within the member state, regardless whether there was an intent to cause an effect within that forum.

\section{The Effects Test in the United States}

\section{Background: Calder v. Jones}

What has come to be referred to as the effects test originated in a U.S. S upreme Court decision in the context of print media, Calder v. Jones, 465 U.S. 783 (1983)(Calder). Florida residents who had esse ntially no physical contacts with California wrote and edited an article in the National Enquirer which defamed Jones, a well-known movie actress residing in California. The Enquirer had greater circulation in California than any other state, and the material in the article was based on California sources. The Supreme Court in a relatively brief opinion found jurisdiction, holding that California was "the focal point both of the story and the harm suffered." The Court in doing so felt compelled to distinguish one of its earlier decisions holding that "foreseeability" of an impact in the forum, standing alone, is not a basis for specific personal jurisdiction. The Court held that the instant facts involved more than foreseeability. Instead, allegedly defamatory articles were published under circumstances sufficient to establish that the defendants' actions were "aimed at California": defendants knew their article would have a "potentially devastating impact" on the California plaintiff and that "the brunt of that injury" would be felt by her in California, hence the defendants could have reasonably foreseen being brought into court in California.

Since the unanimous opinion by Justice Rhenquist in Calder contains minimal explication, it is important to focus on exactly how and why the Court arrived at its result. First, the case involved defamation, the gravaman of which is damage to a person's reputation in the community. The "community" is therefore a factor in defining the tort. Second, presumably because California is among jurisdictions that require malice as an element of libel when a public figure (such as television actress Jones) is involved, the Calder defendants were accused of acting "maliciously and with intent to injure, defame and disgrace" Jones and cause her "to suffer humiliation and emotional and physical distress." Third, the general rule in California is that everyone who takes a responsible role in a defamatory publication is liable. Fourth, the Renquist opinion placed great stress on a fact not mentioned by the California court: that the National Enquirer's largest circulation was in California, where 600,000 copies ("twice the level of the next highest state") were sold. Fifth, defendant Calder not only edited the article in its final form, but once it had been published, he refused to print a retraction. This unique blend of law and facts produced 
an understandable result. It is also worth noting that in finding jurisdiction at the state level, the California Court of Appeal had been obliged to distinguish a prior California Supreme Court case holding that merely causing of an effect in California is not a basis for jurisdiction, pointing out that the prior case was a contract action not involving an "intent to cause a tortious effect within the state."

\section{Evolution of Calder's Effects Test}

As the Supreme Court stated prior to Calder, mere foreseeability that an act may have an effect in a forum state ought not to suffice for specific jurisdiction over a defendant, World-Wide Volkswagen Corp. V. Woodson, 444 U.S. 286 (1980). Calder was based on a malicious and specifically-intended effect within the forum, not on the foreseeability of an effect and certainly not on the mere occurrence of an effect

There are several important aspects to note about Calder and its progeny. First, Calder involved an intentional tort-defamation-rather than negligence or a contractual dispute. Defamation is arguably the cause of action most suited for the effects test, because defamation cannot exist unless the defamatory material is perceived by someone (other than the plaintiff). A matter of practicality also kicks in: it is easier for a court to find that the greatest impact of a defamation to occur where the plaintiff is best known, i.e., where the plaintiff lives and works. All these factors do not always unite in other torts. Other kinds of torts, such as interference with contract, misuse of trade secrets or patent infringement, may cause an effect, i.e., financial injury, to the plaintiff in its domicile, but the tort may have been fully formed without ever touching that domicile, or the defendant may not have focused on inflicting injury there. Courts applying Calder outside the defamation context have produced a mixture of broad and narrow interpretations.

Second, quantitative tests can be useful in measuring intent to cause an effect within the forum. For example, in Calder the largest single-state circulation of the offending publication occurred in California. Not many courts that have purported to apply Calder have been able to cite a powerful fact like this to buttress jurisdiction. Third, the person affected in Calder was an individual. If the person affected is not a natural person, it may be more difficult to associate that person with a single forum. For example, prior to Cybersell the Ninth Circuit had dodged reaching a conclusion as to whether corporations can invoke the effects test. It found there was no jurisdiction in California over Swedish doctors in an antitrust and libel action based upon articles published in international medical journals which had unfavorably compared the dental implants manufactured by the California plaintiff with those made by a Swedish firm, Core-Vent Corp. v. Nobel Industries AB, 11 F.3d 1482 (9th Cir. 1993) (Core-Vent).

\section{Personal Jurisdiction on the Internet}

\section{Evolution of the "Sliding Scale" Test}

Early cases involving jurisdiction in cyberspace in the U.S. were marked not only by inconsistencies, but also by failure to appreciate the technological realities of the new medium. One example was a decision of the Connecticut federal court in 1996, Inset Systems, Inc. v. Instruction Set, Inc., 937 F. Supp. 161 (D. Conn. 1996) (Inset). Inset Systems sued Instruction Set ("ISI") in Connecticut (Inset's home) for trademark infringement, even though ISI had no assets in Connecticut and was not physically transacting business there. The federal district court determined that it had specific personal jurisdiction over ISI in Connecticut, basing its determination on ISI's use of a toll-free telephone number and the fact that there were at the time 10,000 Internet users in Connecticut, all of whom had the ability to access ISI's website. It found the advertising to be "solicitation of a sufficiently repetitive nature to satisfy" the requirements of Connecticut's long-arm statute, which confers jurisdiction over foreign corporations on a claim arising out of any business in Connecticut, Inset. The court also held that the minimum contact test of 


\section{Determining Jurisdiction In Cyberspace}

the due process clause of the Fourteenth Amendment was satisfied, reasoning that defendant had purposefully "availed" himself of the privilege of doing business in Connecticut in "d irecting" advertising and its phone number to the state, simply because subscribers could access the website.

The Inset court failed to appreciate adequately that any website can be accessed worldwide by anyone at any time. Moreover, it failed to give weight to the lack of evidence that any Connecticut residents actually had accessed the site or made a toll-free call to ISI. Under the court's line of reasoning, any website would be subject to jurisdiction everywhere just by virtue of being on the Internet.

The notion that a passive website triggers jurisdiction over on alleged trademark infringer when it is accessible from the forum was subsequently rejected by the Southern District of New York in Bensusan Restaurant Corp. v. King, 937 F. Supp. 295 (S.D.N.Y. 1996), aff'd 126 F.3d 25 (2d Cir. 1997), without citing Inset, and the Second Circuit affirmed. The website in Missouri offered tickets to a local jazz club, but none had ever been ordered by any resident of New York, where a famous jazz club with the registered mark was located. The district court held that "creating a site, like placing a product into the stream of commerce, .... without more . . . is not an act purposefully directed to the forum state."

In an early Sixth Circuit decision involving combined trademark and copyright claims, the Sixth Circuit found extensive contacts warranting jurisdiction. Compuserve Inc. v. Patterson, $89 \mathrm{~F} .3 \mathrm{~d} 1257\left(6^{\text {th }} \mathrm{Cir}\right.$ 1996) involved a computer information and network service which sued a subscriber with whom it had entered into an agreement to register the subscriber's "shareware" computer software for third parties to use and purchase on the Web. Plaintiff sought declaratory judgment that it had not infringed on the subscriber's common law trademarks or otherwise engaged in unfair competition.

After the federal district court had dismissed for lack of personal jurisdiction, the Sixth Circuit reversed. It found specific jurisdiction based on the fact that the defendant had not only entered into a written contract with the plaintiff which provided for application of Ohio law, but had "purposefully perpetuated the relationship" via repeated communications with plaintiff's system in Ohio and by using plaintiff to market his wares in Ohio and elsewhere through plaintiff's Internet system. Defendant also repeatedly sent his "goods" electronically to plaintiff in Ohio for ultimate sale, and after deciding that the plaintiff's product infringed on his software, repeatedly sent messages to Ohio outlining his claim.

The same year Inset was decided, a Pennsylvania federal district court generated the first overall analytical framework for testing specific personal jurisdiction based on the level of Internet activity: Zippo Mfg. Co. v. Zippo Dot Com. Inc. ("Zippo"). Zippo created a "continuum," or sliding scale, for measuring websites, which fall into one of three general categories: (1) passive, (2) interactive or (3) integral to the defendant's business. The "passive" website is analogous to an advertisement in Time magazine; it posts information generally available to any viewer, who has no on-site means to respond to the site. Courts ordinarily would not be expected to exercise personal jurisdiction based solely on a passive Internet website, because to do so would not be consistent with traditional personal jurisdiction law. An "integral" website is at the other end of the continuum: it is used actively by the operator to conduct transactions with persons in the forum state, receiving on-line orders and pushing confirmation or other messages directly to specific customers. In such cases, traditional analysis supports personal jurisdiction. The middle category is the "interactive" website, which falls between passive and integral. It allows a forum-state viewer to communicate information back to the site, by toll-free telephone number, regular mail or even e-mail. Under Zippo, exercise of jurisdiction in the "interactive" context is determined by examining the level of interactivity and the commercial nature of the site. Because in Zippo a non-resident California defendant operated an integral website that had commercial contacts with some 3,000 Pennsylvania residents and Internet service providers, the court had no difficulty finding a high level of interactivity and hence jurisdiction.

In Cybersell, Inc. v. Cybersell, Inc. 130 F.3d 414 (9th Cir. 1997 ("Cybersell”), the Ninth Circuit, in sharp contrast to the Connecticut federal court in the Inset case, rejected the notion that a home page 
"purposely avails" itself of the privilege of conducting activities within a jurisdiction merely because it can be accessed there. The plaintiff in Cybersell was an Arizona corporation that advertised its commercial services over the Internet. The defendant was a Florida corporation offering web page construction services over the Internet. The Arizona plaintiff alleged that the Florida trademark infringer should be subject to personal jurisdiction of the Federal court in Arizona because a website which advertises a product or service is necessarily intended for use on a worldwide basis.

In finding an absence of jurisdiction, the Ninth Circuit used the Zippo-type analysis and called the defendant's website "essentially passive." It also concluded that the Florida defe ndant had conducted no commercial activity over the Internet in Arizona. Even though anyone could access defe ndant's home page and thereby learn about its services, the court found that this fact alone was not enough to find that the Florida defendant had deliberately directed its merchandising efforts toward Arizona residents. Accordingly, defendant's activities over the Internet were insufficient to establish "purposeful availment." In so ruling, the court observed that, if all that were needed for jurisdiction was access in the forum to an infringing web page, "every complaint arising out of alleged trademark infringement on the Internet would automatically result in personal jurisdiction wherever the plaintiff's principal place of business is located," Cybersell. The court also rejected application of the effects test. It saw the passive website as different from a publication with a large California audience. It also distinguished between the effects in the plaintiff's residence when the plaintiff is a corporation "which does not suffer harm in a particular geographic location in the same sense that an individual does" and an intentional defamation of a specific, real individual and the infringement of a trademark owned by a corporation, Cybersell.

After Zippo and Cybersell, courts became increasingly reluctant to grant jurisdiction merely on the basis of the number of people in the forum jurisdiction who can access a passive website, even where accessibility is accompanied by other means of communicating with the site operator or by a small amount of other contacts with the forum. Indeed, the Connecticut Superior Court, without even a reference to the Connecticut federal court's opinion in Inset, ruled in 2000 that specific jurisdiction could not be based on the mere accessibility within Connecticut of a website operated from Georgia. When the Connecticut federal district again considered jurisdiction based on a website in 2001, it wholly disregarded its own opinion in Inset, stating that "most courts follow the lead of . . Zippo," On-Line Technologies v Perkin Elmer Corp., 141 F.Supp. 2d 246 (D.Conn. 2001). After the Ninth Circuit's implied endorsement of the Zippo model in Cybersell, five other federal circuits elected to recognize or adopt that model. The Fifth Circuit did so in Mink v. AAAA Devel. LLC, 1909 F.3d 333 ( $5^{\text {th }}$ Cir 1999) finding that a printable mail-in form, a toll-free call- in number and a posted e-mail address were not enough to impose specific jurisdiction in Texas over a Vermont website operator. Because orders were not taken through the website, it was deemed to be nothing more that a "passive advertisement." In the same year, the Tenth Circuit used the Zippo analysis in holding that a "passive" website was insufficient for exercise of jurisdiction in Utah over a British bank, Soma Medical Intern v Standard Chartered Bank, 196 F.3d $1292\left(10^{\text {th }}\right.$ Cir 1999).

The sliding-scale nature of Zippo becomes vulnerable to subjective results when applied. Sometimes the question as to whether to place a site in the "interactive" or "integral" category may turn more on a court's perception than on real differences in the manner in which the user employs the Inte rnet. For example, a judge in the Southern District of New York, while acknowledging that plaintiffs' allegations that defendants' mobile telephone and two-way e-mail services were used in New York to be "factually unsupported," nevertheless found the mere availability of the defendant's website in New York made it "intuitively apparent" that defendant's services were used by New York residents, thereby establishing a basis for jurisdiction as an interactive site, Cable News Network, L.P. v. GoSMS.com, Inc., 2000 WL 1678039 (S.D.N.Y.). In effect, this was judicial transposition of a passive website into a highly interactive website. 


\section{Evolution of the Effects Test in Cyberspace}

The first decisions involving the effects test in cyberspace were decided the same year as Zippo. In Edias Software Intern. v. Basis Intern. Ltd., 947 F. Supp. 413 (D. Ariz. 1996). The Arizona federal district court sustained jurisdiction over a New Mexico software distributor which had allegedly posted on its website and e-mailed to Arizona material defaming plaintiff. The co urt held the allegations that the materials were directed at Arizona and allegedly caused foreseeable harm to plaintiff was a basis for jurisdiction under Calder.

The Northern District of Illinois invoked the Seventh Circuit's relaxed interpretation of Calder in a trademark case, Bunn-O-Matic Corp. v. Bunn Coffee Service Inc, 46 U.S.P.Q.2d 1375 (N.D. Ill. 1998) (Bunn-O-Matic.) Without citing Zippo (which had been decided over two months earlier), the court found defendant's website "passive," since no orders could be placed on the site, no Illinois residents had entered the site's contest online, its toll free numbers were inaccessible to Illinois residents and defendant did not advertise, sell or ship into Illinois. However, relying on the effects the court found jurisdiction, "although Bunn-O-Matic does business all over the country, it is reasonable to conclude that the injury of trademark infringement will be felt 'mainly' in Illinois,"(Bunn-O-Matic.)

The Ninth Circuit was the first federal appellate court to invoke the effects test in the online environment, thus declining to find jurisdiction. In Cybersell, Inc. v. Cybersell, Inc., 130 F.3d 414 (9th Cir. 1997) ("Cybersell") an Arizona plaintiff provided Internet marketing services through its website under the registered service mark "Cybersell." The Florida defendant provided business consulting services through its website under exactly the same name. At the time defendant chose the name "C ybersell," plaintiff's website was not operational, nor had the Patent and Trademark Office yet granted plaintiff's application for its service mark. Plaintiff instituted suit in the District of Arizona, alleging, inter alia, trademark infringement. As discussed earlier, the Ninth Circuit found no jurisdiction under the Zippotype continuum. It also determined there was no jurisdiction under the effects test, because defendant's website was "not aimed intentionally at Arizona knowing that harm was likely to be caused there," $C y$ bersell. Thus, the mere act of registering another's trademark as a domain name and posting an infringing but passive site on the Internet should not, without more, subject a non-resident to personal jurisdiction in the forum state.

The Ninth Circuit found the "something more" that was lacking in Cybersell in a later case involving an Illinois resident who operated a "cybersquatting" scheme, Panavision Int'l, L.P. v. Toeppen, 144 F.3d 1316 (9th Cir. 1998) (Panavision). The Illinois defendant registered exclusive Internet domain names that contained registered trademarks belonging to others. He demanded fees from Panavision, a wellknown California resident, as his price for relinquishing rights to domain names that corresponded to Panavision's existing trademark registrations. The "something more" consisted of defendant's efforts to "extort" money from a plaintiff whose business and trademarks were particularly well-known in California. The court thus viewed defendant in Illinois as having committed a tort which "is aimed at or has an effect in the forum state." The result in this case demonstrates a positive outcome using the effects test.

It was earlier suggested that the utility of the effects test may be greater with certain causes of action than with others. The following discussion traces the application of the effects test in defamation and trademark cases.

Defamation Since the Supreme Court decided the Calder doctrine in a case involving defamation of a public figure, it is logical that defamation is the type of cause of action where the courts can best apply the effects test. This is because intent to cause harm is an element of the defamation cause of action that it lends itself so easily to an effects test for jurisdiction. However, Calder also stressed the quantity of printed material being shipped into the plaintiff's residence. A passive website in cyberspace is different from a printed periodical. Whereas a periodical must be shipped in quantities into various states to 
newsstands and other distribution points and mailed to subscribers, content on the Web is not "shipped" but simply posted. Some courts are therefore understandably reluctant to agree that defamatory material posted on the Internet, which is accessible from multiple states and countries simultaneously on a nonselective basis, subjects the defaming party to jurisdiction in every forum from which the defamatory material can be accessed, unless very specific intent is discernible.

It is also important to recognize the difference between having a regularly distributed publication as defendant and having its individual reporters or editors as defendants. That difference is exemplified by a case decided by the U.S. Supreme Court the same day as Calder, Keeton v. Hustler Magazine, Inc, 465 U.S. 770, 780 (1984). Where the defendant is a publication distributed regularly in a state, it will likely be held sufficiently "present" in the state to meet due process requirements without the need to resort to the effects test. An Ohio resident was thus allowed to bring a libel action against the publisher of Hustler Magazine in New Hampshire - the only state in which the statute of limitations had not yet runeven though it was undoubtedly true that the bulk of the harm done to petitioner occurred outside New Hampshire. The publisher in Keeton regularly circulated copies of magazines in the forum state and New Hampshire had a "significant interest in redressing injuries that actually occur within the State," whether or not suffered by its own residents, hence the Court found jurisdiction proper, Keeton v. Hustler Magazine, Inc. In Calder, in contrast, only individuals, who are viewed separate from the per iodical, were contesting jurisdiction.

A number of courts have invoked the effects test in declining to find jurisdiction over defamation claims. For example, a psychiatrist in Pennsylvania brought suit against an Oregon resident in Pennsylvania for allegedly defamatory statements on the defendant's Oregon website. The federal district court found a lack of jurisdiction in Pennsylvania under either Zippo or the the effects test, Barrett $v$. Catacombs Press, 44 F. Supp. 2 d 717 (E.D. Pa. 1999). The court found that the website statements concerning plaintiff related to his non-Pennsylvania activities and his nationally-recognized health ad vocacy, hence were not "expressly aimed" at Pennsylvania. Mere foreseeability of an effect on the plaintiff in Pennsylvania is not enough; harm within the state from out-of-state conduct must be "deliberately or knowingly targeted by the tortfeasor."

In English Sports Betting, Inc. v. Tostigan, 2002 WL 461592 (E.D. Pa) (English Sports Betting, Inc) the Eastern District of Pennsylvania, applying the effects test, found that a Virginia website operator published allegedly defamatory articles about the plaintiff, an offshore gambling business owner residing in Pennsylvania. The plaintiff attempted to establish jurisdiction based primarily on the effects test due to the articles' discussion of the plaintiff's criminal background in Pennsylvania. The court held that the effects test was not satisfied because "[t]he recipient audience is not linked by geography but by a common interest in off- whore sports gambling," further stating that even if it could be proven that the brunt of the harm was suffered in Pennsylvania, there was no proof that the defendant's tortious conduct was expressly aimed at Pennsylvania. It further found that "[t]here is a difference between tortious conduct targeted at a forum resident and tortious conduct expressly aimed at the forum," and the court held that the former is not sufficient to satisfy the effects test, English Sports Betting, Inc.

The court in English Sports Betting, Inc. further held that "it is not sufficient that the brunt of the harm falls within plaintiff's home forum, even when this was reasonably foreseeable." Although the defendant published information that could potentially have a significant impact on the plaintiff's Pennsylvania residence, the court declined to exercise personal jurisdiction based on the effects test because foreseeability of harm was not enough.

The Western District of Tennessee reached a similar result where allegedly defamatory material was posted on the website of a Florida aircraft engine developer, Bailey v. Turbine Design, Inc., 86 F. Supp. 2d 790 (W.D. Tenn., E. Div. 2000). After finding the website purely passive under Zippo, the court invoked the effects test to reject jurisdiction over the nonresident defendant. It observed that plaintiff had 


\section{Determining Jurisdiction In Cyberspace}

been attacked on defendants' site in his capacity not as a Tennessee businessman, but as a nationwide and worldwide competitor in aircraft conversions. Citing the foregoing case of the Pennsylvania psychiatrist discussed above, it ruled that mere foreseeability of harm in the plaintiff's forum state was insufficient to satisfy Calder's requirement of intentional targeting.

The same Florida aircraft engine developer was also sued in the Northern District of Mississippi for defamation and tortious interference claims asserted by a Mississippi aircraft engine developer, Lofton $v$. Turbine Design, Inc., 100 F. Supp. $2 \mathrm{~d} 404$ (N.D. Miss. 2000). The outcome was similar. Stating that jurisdiction was to be determined under Zippo (which the Fifth Circuit had adopted in Mink), the court found jurisdiction could not be based on defendant's "passive" website. The court also considered and rejected arguments under the effects test on the basis that (a) the website information focused on a Tennessee resident, not on Mississippi, and (b) to base jurisdiction upon a website's accessibility would in any event run counter to Mink.

When a Texas resident sued the Board of Trustees of Columbia University and others in New York for allegedly defaming him in an article about the bombing of a Pan Am flight posted on Columbia's Internet bulletin board, a federal court in Dallas followed a similar analysis, Revell v. Lidov, $2001 \mathrm{WL}$ 285253 (N.D. Tex.). Thus, it first invoked Zippo to determine that the bulletin board "fits perfectly into the passive website extreme." Turning to the effects test, the court held that the allegedly defamatory article did not target Texas. It viewed the article as criticizing plaintiff in his role as an FBI official, "the one person in the United States" responsible for the FBI programs maligned by the article, and not in his role "as a resident ... or co mmunity leader in the state of Texas, Revell v. Lidov.

Trademark Infringement In assessing the use of the effects test in trademark infringement actions, it is important to bear in mind that while intent to cause injury is not a required element of the tort, it is at the core of the effects test. The Ninth Circuit was the first appellate circuit to use the effects test to defeat jurisdiction in a trademark case in Cybersell. The Ninth Circuit in Panavision used a slightly modified version of the effects test to sustain jurisdiction in a trademark case based on website activity. Critical to its decision was the fact that the Illinois defendant had attempted to sell his infringing domain names to the acknowledged California copyright owner; this fact sustains the conclusion that the defendant was targeting the plaintiff in California. Panavision should therefor not be interpreted to stand for the looser principle, adopted in the Seventh Circuit cases discussed below, that the effects test applies simply if a trademark owner's mark is well known and associated with a given geographical location.

Sports Authority Michigan, Inc. v. Justballs, Inc., 97 F. Supp. 2d 806 (E.D. Mich. 2000) presents an application of the effects test where the facts were sufficient for jurisdiction over a trademark infringement claim under Zippo. The federal court in Michigan felt compelled to buttress its holding of jurisdiction by also finding the defendant may have "targeted" Michigan residents by selling merchandise online that contained logos of Michigan sports teams. The court did not need to invoke effects test, since it could easily have based jurisdiction by relying on Zippo alone.

The effects test was used to defeat jurisdiction in Spacey v. Burger, 2001 WL 1869857 (C.D. Cal) where a Canadian operator of the "Kevin Spacey Club," registered and used the domain name "kevinspacey.com" without authorization from the well-known movie actor. Defendant then licensed use of the domain name to an affiliate that operated a web "celebrity guide" with information on show-business news and personalities. Spacey, a well-known former California resident now domiciled in New York, sued in California federal court for misappropriation of his name. The Central District of California found a lack of specific personal jurisdiction over the Canadian defendant. It distinguished Panavision because (1) here the defendant was not attempting to extract payment for the domain name and (2) the celebrity guide website was not aimed at either the entertainment business or Southern California. The court concluded that the defendant was not targeting California and "the brunt of any harm to Spacey's name and goodwill caused by defendants' alleged wrongdoing would not reasonably be felt here." Al- 
though Spacey adduced evidence of advertisements on defendant's celebrity website relating to California, the court ruled that the advertisements did not solicit business for defendant, but rather for the advertisers.

Courts in the Seventh Circuit, which have loosely applied the effects test, have been inconsistent on the question whether an infringing website should be deemed to be aimed at the owner of a trademark in the place of his residence. In Transcraft Corp. v. Dornan Trailer Corp., 45 U.S.P.Q.2d 1097 (N.D. Ill. 1997) the Northern District of Illinois ignored the effects test altogether; it found no jurisdiction over a defendant whose website was viewable and accessible in Illinois, provided Illinois residents with tollfree numbers and addresses, provided sales information and invited Illinois residents to contact them via telephone or email, drawing essentially on Zippo. But in Bunn-O-Matic v. Bunn Coffee Service, Inc., the Central District of Illinois found jurisdiction over the New York defendant because its passive website was accessible in Illinois. It reasoned that the forum in which the victim of a tort (here, trademark infringement) suffers injury may entertain jurisdiction over the alleged tortfeasor and that it was "reasonable to conclude" that the injury would be felt "mainly" in Illinois. The same court in McMaster-Carr Supply Co. v. Supply Depot, Inc, 1999 WL 417352 (C.D. Ill.), held that the effects test was automatically satisfied when the defendant registered the plaintiff's mark as its domain name on a passive website knowing that the conduct would harm plaintiff in Illinois, its principal place of business.

One federal court has gone to great pains in attempting to formulate a complex rationale to determine when the owner of a trademark should be deemed targeted in his home jurisdiction by dint of another party using the mark in a domain name. In Ford Motor Company v. Great Domains, Inc., 141 F. Supp. 2d 763 (E.D. Mich., S. Div. 2001) (Ford Motor Company) Ford and its affiliates, such as Ja guar and Volvo, sued more than 80 persons and entities who registered Internet domain names incorporating "Ford," "Jaguar," "Aston," "Volvo," and other marks in which Ford claimed an interest, alleging trademark infringement, dilution, false designation of origin and cyberpiracy. Citing cases based upon

Zippo's sliding scale, the Eastern District of Michigan indicated there would be no basis for jurisdiction on the nature of the website, which site was passive and produced no Michigan transactions. The court then turned to the effects test, finding with little difficulty that (1) the brunt of the injury was felt in Michigan and (2) defendants' use of Ford marks in the domain name was intentional or deliberate.

What the court found more daunting was the question whether defendants' acts were "expressly aimed" at the state of Michigan. Arguably, a loose reading of Panavision could have produced a basis for jurisdiction over the "Ford" marks, since the ir fame and association with Michigan clearly surpasses Panavision's fame and association with California. However, the court rejected plaintiff's argument that, merely by incorporating a famous mark into a domain name, a defendant assumes the risk of jurisdiction in the trademark owner's home forum. Instead, the court sought to determine under what circumstances the act of registering a trademark as an Internet domain name is "expressly aimed" at the mark owner's place of residence. Finding no authoritative case law directly addressing the issue, the court constructed a two-factor test for determining whether the act of registering a domain name is "expressly aimed" at a trademark owner: "(1) the likelihood of confusion as to who controls the domain that is created by the domain name itself and (2) the level of individualized targeting at the trademark owner," adding that "these factors are inversely proportionate to each other," (Ford Motor Company). If there is a high likelihood of confusion created by the domain name is high, a low-level showing of individual targeting will suffice. However, if the likelihood of confusion is low, a high level of ind ividual targeting is required. In turn, likelihood of confusion is tested by two factors (1) the existence of other legitimate uses for the exact mark and (2) the "lexical context of the mark within the domain name," (Ford Motor Company). For example, "4fordtrucks.com" has no "lexical content" other than vehicles, hence it "plainly" impIcated Ford as the probable source and thus created a "high likelihood of confusion." In comparison, since "vintagevolvos.com" could suggest Volvo enthusiasts as well as the automobile, the court found the likelihood of confusion to be low. 
In assessing the level of individual targeting, the court saw the key considerations as: (1) whether the trademark owner has been directly solicited to purchase the domain name; (2) whether the domain name registrant has registered domain names incorporating other protected marks; (3) whether the domain has been offered for sale by the owner and, if so, the price sought; (4) whether the domain owner has a preexisting, legitimate use for the domain name; and (5) any other factors which demonstrate that the act of incorporating the protected mark into a domain name was "expressly aimed" at the forum in which the trademark owner resides. Applying this mode of analysis, the court concluded that three of the domain names involved in the case created a high likelihood of confusion, three created an "intermediate likelihood of confusion," and three others created a "low likelihood of confusion," (Ford Motor Company.) The court noted a difference in two circuits as to whether a corporation necessarily feels the brunt of an injury where its headquarters are located. The court indicated that by allowing jurisdiction only on a clear showing of targeting, there was no reason to treat a corporation differently from an individual.

\section{Enforcement Jurisdiction and the Yahoo! Case}

The recent lawsuit by the International League Against Racism and Anti-Semitism and the Union of French Law Students against Yahoo!, (Yahoo! Inc., v La Ligue Contre Le Racisme Et L'Antisemitisme, 169 F.Supp 2d 1181, 2001)(Yahoo!), which has received a lot of attention in the popular press summarizes the difficulties that remain in resolving both the prescriptive and enforcement jurisdictional issues in cyberspace. Two French groups, namely the Union of French Law Students and the International League Against Racism and Anti-Semitism filed suit against Yahoo! for hosting auctions that displayed and sold Nazi propaganda. The memorabilia auctions were accessible only via the English language site, Yahoo.com. Direct access through Yahoo.fr was not possible. Yahoo! argued in French Court that the French Court did not have jurisdiction over Yahoo!. That plea was denied, and in November of 2000, a French court ruled that Yahoo! must put filtering systems in place to block users in France from access to the Nazi related goods area, or pay fines of approximately $\$ 13,000$ per day. Only a watered down version of the effects test could be seen to apply to the French court's decision in this case and since Yahoo! was not targeting France which is a key element in the effects test the assertion of jurisd iction arguably violates the due process requirement of U.S. law (Rice, 2002).

Yahoo! chose not to appeal the French court's judgment but rather it challenged the enforcement of the order in the United States. In December of 2000, Yahoo! filed a lawsuit in the United States District Court of Northern California seeking a declaratory judgment that any final judgment of a French court would be enforceable in the United States. Before the California court could address the merits of the case, in a bit of an ironic twist, the French defendants motioned the California court to dismiss the declaratory judgment suit due to lack of jurisdiction. The U.S. court denied the motion to dismiss, finding jurisdiction based upon the effects theory. The court ruled that the defendant knowingly engaged in the activities and intended to have an effect on the United States citizens, for example, the use of U.S. Marshals to serve Yahoo! officers in California. Clearly, the French citizens purposely availed the mselves of the benefits of the United States.

A state can only enforce its laws against a defendant in a forum where the defendant can be found or where there are assets belonging to the defendant. Enforcement of a judgment rendered by another forum requires its recognition by another court to enforce it. If it is the jud gment of a court in a state in the United States, the Full Faith and Credit Clause of the Constitution requires that it be recognized by another state. When recognition of a judgment of a foreign court is sought in the United States it depends upon the principle of "comity." Comity is not a matter of absolute obligation but it is the recognition which one nation allows within its territory to the legislative, executive or judicial acts of another nation. National procedures required for recognition and enforcement of judgments vary widely around the globe. In the United States, comity is upheld unless to do so would violate due process, personal jurisdiction or some public policy. 
In order to determine the enforcement jurisdiction of the French court over Yahoo!, the Federal District Court for the Northern District of California found the issue to be whether it was consistent with the Constitution and the Laws of the United States for another nation, namely France, through their court order, to curtail the Yahoo! website. The French therefore would be regulating speech by United States' residents within the United States on the basis that such speech could be accessed by Internet users in France. The Court was mindful of the extent to which the United States is governed by the "comity of nations" but did not believe that comity was a matter of absolute obligation. The Court decided the case in accordance with the Constitution, finding that the French Order violated the Constitution of the United States, thereby recognizing that it was necessarily adopting the position that "certain judgments embedded within this enactment including the fundamental judgement expressed in the First Amendment that it is preferable to permit non-violent expression of offense viewpoints then to impose vie wpoint based government regulation upon speech, "Yahoo!.

The Court rendered judgment in favor of Yahoo! in a summary judgment motion that they requested on the declaratory judgment action to find the French Order in violation of the First Amend ment. This finding of a threat to Constitutional rights by the Court was the grounds by which it effectively rendered the Order unenforceable and which demonstrates the limits of perspective jurisdiction. This case suggests the disharmony that continues to exist among nations on questions of jurisdiction.

It appears that courts and legislatures have found legitimate grounds for asserting prescriptive jurisdiction over defendants based upon actions taken in cyberspace, but that may have little importance when the plaintiff seeks a restorative remedy. Enforcement jurisdiction, which requires the injured party to attach either the defendant or his tangible assets, becomes an issue of comity or state's recognition of its obligation to enforce a law. Questions of comity have not been resolved sufficiently to assure smooth enforcement on the Internet. Policy makers and governments will need to address this higher level of enforcement jurisdiction to foster predictability and certainty necessary for the growth of commerce on the Internet.

\section{Conclusion}

Currently, a U.S. court dealing with the issue of jurisdiction over a non-resident based on his online activity will probably start its inquiry by using a Zippo analysis, but it is increasingly likely that courts will further analyze the issue by applying the effects test, particularly where the case involves a tort claim or where the defendant's website is either passive or only modestly interactive under Zippo. It is therefore advisable for attorneys advocating jurisdiction to use both tests, since the effects test may work where the sliding-scale of Zippo might not.

The effects test like the Zippo test is not free from subjectivity. The issue of jurisdiction is often decided at the threshold of litigation on the pleadings and inferences drawn from the pleadings. The same set of facts that might lead one court to conclude that a defendant intended purposefully to cause an effect within a given jurisdiction might not lead another court to the same conclusion. Moreover not all courts have been equally rigorous in requiring that the forum itself have been purposely targeted in order to invoke the effects test. "Targeting" to some courts simply connotes an effort specifically to reach a person who resides in the forum, rather than to generate an impact there. To other courts, it may only connote that effects within the forum were foreseeable. In the end, the cases suggest that predictability of outcome is perhaps only marginally greater under the effects test than under the sliding-scale test.

While defendant's intent to inflict injury within the forum must be determined by specific facts in specific cases, several factors are useful in measuring that intent. First and foremost, courts should insist on something beyond accessibility of the defendant's website. There should be allegations of specific intent to inflict damage to the plaintiff within the forum where he resides. There should be a showing that the content in question impacted upon at least a critical mass of actual viewers in the jurisdiction. If the 


\section{Determining Jurisdiction In Cyberspace}

information about Shirley Jones had not been printed in 600,000 copies of the National Enquirer that were distributed in California, but rather posted on a password accessible website used only by registered academics, the factors relied upon in Calder would not logically yield the same result.

Beyond allegations of actual intent and impact on relevant persons inside the forum, there are circumstantial factors that courts can consider in determining effect whether targeting of the forum occurred. For example, one is the selection of language in which information is communicated. Initially, the great majority of communication on the World Wide Web was in English, and while the proportion of nonEnglish sites is increasing, the language is still so common that its use on a website would not be suff icient to establish the jurisdiction of an English-speaking country. In contrast, a site in Hindi could be considered to be targeted at residents of India, just as securities offerings posted in Dutch on the Internet are a factor considered by Dutch securities regulators in determining if they are targeted at residents of the Netherlands. Closer to ho me, a political webcast in Spanish on a largely Spanish-language site located in Texas but disparaging a candidate in California, could be said to target Latino voters in California.

Currency can be another such factor: when services are quoted in a currency other than that of the website's domicile, this would arguably be evidence of intent to reach that jurisdiction. Again, widely used currencies, such as the U.S. dollar, or generic currencies like the Euro, should not be considered evidence, taken alone, of targeting. As technology advances, the use of "push" technology would likely be viewed as targeting activity that warrants specific jurisdiction in the location of the pushee.

While courts are refining the effects test as described above, courts will continue to rely upon the passive/active analysis of Zippo to evaluate highly interactive or integral websites, particularly in cases involving negligent and non-malicious business torts and breach of contract. Certain torts, such as defamation and many intentional violations of intellectual property laws, are suitable for the effects test. This suggests that as we look to the future, tests for finding jurisdiction may be based upon the type of cause of action or case in controversy. In fact, rather tha $\mathrm{n}$ seeking harmony in rules for jurisdiction across borders, it may be more productive to seek uniformity in standards for jurisdiction based along subject matter lines.

\section{References}

Council Regulation on Jurisdiction and the Recognition and Enforcement of Judgements in Civil and Commercial Matters, Council Regulation (EC) No. 44/2001, 22 December 2000, Official Journal L 012, 16.01.2001, http://europa.eu.int/eurlex/pri/en/oj/dat/2001/1_012/1_01220010116en00010023.pdf

Geist,M. (2001).Is There a There There: Towards Greater Certainty in Internet Jurisdiction, 16 Berkeley Tech.L.J. 1345.

Jupiter Research. (2002). http://www.jupitermedia.com/

NUA Surveys. (2002). http://www.nua.com/surveys/

Reflection Paper To Assist in the Preparation of aConvention on Jurisdiction and Recognition and Enforcement of Foreign Judgements in Civil and Commercial Matters, Hague Conference on Private International Law http://www.hcch.net/e/workprog/jdgm.html

Rice, D. (2002). Refining the Zippo Test: New Trends on Personal Jurisdiction for Internet Activities. The Computer \& Internet Lawyer. Prentice Hall Law\& Business.

\section{Biography}

Julia Alpert Gladstone is a professor of Legal Studies at Bryant College in Smithfield Rhode Island, USA. She researches the relationship between technology and the law particularly as it is revealed on the Internet. Her own writings cover a broad range of emerging areas of concern in cyberspace and she has been invited to speak in numerous locales around the globe. 